\title{
Study of different extraction methods on finger print and fatty acid of raw beef fat using fourier transform infrared and gas chromatography-mass spectrometry
}

https://doi.org/10.1515/chem-2018-0109

received March 6, 2018; accepted May 21, 2018.

\begin{abstract}
Beef fat was an extracted fat that a byproduct of beef processing industry. In this research, the objective was to study the effect of extraction methods on finger prints and fatty acid profiles of beef fat and to obtain the chosen extraction method. This study consisted of two steps namely extracting beef fat using Soxhlet, Folch, Bligh and Dyer, and Hara and Radin methods as well as characterizing the finger print using FTIR and fatty acid profiling using GCMS. The total lipid by Soxhlet, Folch, Bligh \& Dyer, and Hara \& Radin methods were 89.67\%, $81.73 \%$, 55.16\%, and $84.40 \%$, respectively. Statistical analysis showed that the saturated fatty acid in Folch was not significantly different with that in Soxhlet and Hara and Radin at a 5\% level. Polyunsaturated fatty acids such as linoleic and linolenic acids are present in all methods, where linoleic acid was the highest in Folch and linolenic acid was the lowest in Bligh and Dyer. The PCA analysis showed that only Folch that can be differentiated and has minimal residual error values. The results of the finger print analysis showed the extraction methods which were used are not different. These data showed that Folch was the chosen method for extracting beef fat.
\end{abstract}

Keywords: beef fat; extraction; fatty acid; finger print analysis; force constant.

\footnotetext{
*Corresponding author: Aminullah, Department of Food Technology and Nutrition, Faculty of Halal Food Science, Djuanda University, Bogor, Indonesia, E-mail: aminullah@unida.ac.id Mardiah, Hanna Sutsuga: Department of Food Technology and Nutrition, Faculty of Halal Food Science, Djuanda University, Bogor, Indonesia

Tetty Kemala: Department of Chemistry, Faculty of Mathematics and Natural Sciences, Bogor Agricultural University, Indonesia
}

\section{Introduction}

The analysis method of fatty acid composition by utilizing Gas Chromatography - Mass Spectometry or GC-MS is developed in the verification of the purity of food products containing animal fat [1]. Nina Naqiyah et al. [2] also used this method to compare fatty acid composition of beef fat, lard, chicken fat, and goat fat. Even so, Hermanto et al. [3] characterized beef fat by GC-MS analysis which is combined with Fourier Transform InfraRed (FTIR) analysis. The FTIR method is utilized to analyze the spectrum patterns of a fat product. Typical spectral patterns can describe the animal finger prints [4]. Nurulhidayah et al. [5] analyzed the authenticity of beef fat butter by using this method. Rohman et al. [6] and Guntarti et al. [7] reported pig contamination in beef meatballs accurately using FTIR. Meanwhile, Rohman et al. [6] developed FTIR method to detect beef fat contamination in cod liver oil. In addition, the interaction of infrared radiation with the material can be understood in terms of changes in molecular dipoles associated with vibration and rotation. A molecule can be viewed as a mass system connected by a bond with a springlike property, in which the stiffness of this bond can be characterized by a constant, the force constant, $\mathrm{k}$ (derived from Hooke's law).

The fatty tissue needs to be prepared by sampling with an extraction process. The selection of methods will affect the results of extraction processes and extracted components. Manirakiza et al. [8] showed that the Soxhlet method was better than Bligh \& Dyer for chicken meat, while Ewald et al. [9] found opposite results for fish meat. Pérez-Palacios et al. [10] evaluated six methods of extraction and showed that the Folch method obtained the best results in various meats and processed meat products. Based on these, the study focusses on different extraction methods that will give the specific profiles and characteristics of beef fat. In this study, four extractions by Soxhlet, Folch, Hara and Radin, and Bligh and Dyer methods are used. The Soxhlet method is the most 
common semi-continuous method used for fat extraction from food materials [11]. Pérez-Palacios et al. [10] reported that the Folch method is effective, efficient, and fast for fat extraction on a variety of meats and their preparations with low, moderate, high to very high fat contents. In addition, Aminullah et al. [12] also reported that Folch was the selected method for extracting raw chicken fat. The Bligh and Dyer method can produce a enduement of about $95 \%$ of the total fat even with the reduction of the solvent [13]. While in the Hara and Radin Method, two phases were separated rapidly during the washing step, the solvent density was low enough to allow centrifugation of homogenates as an alternative to filtration and the solvent being cheaper. The objective of the research is to study and evaluate the effect of extraction method on finger print and fatty acid profiles of beef fat using FTIR and GC-MS, respectively, and to obtain the chosen extraction method for extracting beef fat.

\section{Methods}

In this research, there were two parts of research namely extracting beef fat tissue (abdominal fat) using four extraction methods and measuring fatty acid and finger print profiles using GC-MS and FTIR, respectively. The samples were collected at same day and same market and then stored in a freezer. Before the samples were extracted in two replications, the samples were thawed first.

\subsection{Extraction method}

There were four extraction methods which were used in this research namely Soxhlet (SO), Folch (FO), Bligh and Dyer (BD), and Hara and Radin (HR) methods with two replications. The first, second, third, and forth samples of beef fat were extracted by using Soxhlet method based on AOAC [14], Folch et al. [15], Bligh and Dyer [16], and Hara and Radin [17] methods, respectively. Beef fat was prepared by rendering the adipose tissue of beef, obtained from the meat market in Pasar Bogor, West Java, Indonesia. Then, the percentage of the total lipid was calculated.

\subsection{Analysis of fatty acid composition using GC-MS}

After the extraction, the extracted beef fats were transesterified according to Metcalfe and Schmitz [18], separated by gas chromatography - mass spectrometry (Agilent Technologies 7890A Gas Chromatography with
Auto Sampler and 5975C Mass Selective Detector and Chemstation data system) as follows: a $1 \mu \mathrm{L}$ fame was then injected into the GC column by the autosampler method. Separation was done in the HP Innowax capillary column with the injector temperature was set at $260^{\circ} \mathrm{C}$. The oven temperature was programmed where the initial temperature was $50^{\circ} \mathrm{C}$ for $0.5 \mathrm{~min}$, then raised to $195^{\circ} \mathrm{C}\left(8^{\circ} \mathrm{C} / \mathrm{min}\right)$, then raised again to $225^{\circ} \mathrm{C}\left(1^{\circ} \mathrm{C} / \mathrm{min}\right)$ and held for 22 minutes. Helium gas flow rate of $1.86 \mathrm{~mL} /$ min. The MS detector used was Electron Multifier Detector (EMD) $70 \mathrm{eV}$. The mass spectral results were processed by GCMS postrun analysis software. The fatty acid data were expressed as the peak area percentage.

\subsection{Analysis of finger print using FTIR}

The liquid extracted beef fat from previous extractions were placed on the plate of Thermo Scientific Nicolet iS5 FT-IR spectrometer (Thermo Fischer Inc./PT. Alphasains Dinamika). Each time measuring the sample, the plate was cleaned by using pure ethanol solvent pro-analysis then air spectrum was used as a background and recorded in graph and absorbance or transmittance value. The FTIR spectrum was analyzed at wave numbers of $4000-600 \mathrm{~cm}^{-1}$ with 36 times scan using OMNIC Software. The results were in the form of an infrared spectra graph where the graph was the relationship between wave numbers with the transmittance intensity.

\subsection{Statistical Analysis}

Statistical analysis using analysis of variance (ANOVA) and Duncan's posthoc test of SPSS version $21^{\circledR}$ if $p<0.05$ or significantly difference. In order to differentiate fatty acids of beef fat using SO, FO, BD, and HR extraction methods, the chemometrics of principal component analysis was performed with the aid of OpenChrom Community Edition (Diels)

Ethical approval: The conducted research is not related to either human or animal use.

\section{Results and Discussion}

\subsection{Total lipid on beef fat}

The beef fat tissue is extracted by the four previously mentioned methods to determine the total lipid content that can be seen in Table 1. 
Based on the results, it can be seen that the total lipid percentage of $\mathrm{BD}$ is the lowest than the other extraction methods. This is consistent with the results of Iverson et al. [13] which showed that samples containing more than $2 \%$ lipid, the BD method is significantly lower in lipid content than the FO method and the higher the lipid level leads to the greater the difference. In addition, initially BD method was developed for fish samples with fat content less than $1 \%$, and samples with higher content of fat may require modification [16]. Aminullah et al. [20] also stated that total lipid in BD was the lowest than other methods in chicken fat as well as in pork fat. Total lipid of HR method is slightly higher than that of FO method. According to Schlectriem et al. [19], this may be due to the extract of HR method containing less non-lipid than FO extract, so the total lipid in FO will lower than that in HR method. Meanwhile, SO method yields the highest value of $89.67 \%$.

\subsection{Fatty acid composition of beef fat}

Beef fat has diverse fatty acids which is shown in Table 2. Capric acid (C10:0) to 11-eicosanoic (C20:1) acid can be detected using GCMS. According to Sharma et al. [21], beef fat typically contains 9 or 10 dominant fatty acids and estimated contains about 180-200 other fatty acids in very small amounts.

There is little difference in the fatty acid composition of beef fat extracted by various methods. There are six dominant fatty acids which are present in all extraction method namely myristic, palmitic, palmitoleic, margaric, stearic, oleic, and linoleic acids. These results in accordance to Rohman et al. [22] which stated that these fatty acids are dominant in beef fat. The SO method produces a composition similar to that of FO except for cis-10-Nonadecanoic acid (C19:1) which is not detected in the sample. Meanwhile, HR and BD methods give similar results which can detect capric acid (C10:0) to linolenic acid (C18:3). Statistical analysis shows that saturated fatty acid (SFA) in FO is no significantly different with that in SO and HR at 5\% level. While, SFA in FO is significantly different with that in BD which SFA in BD is higher than that in FO. Polyunsaturated fatty acid (PUFA) such as linoleic and linolenic acids are present in all extraction method, where linoleic acid in FO is the highest and linolenic acid in BD is the lowest than others. In addition, cis-10-nonadecanoic acid only presents in FO in small amount.

FO method is an effective and efficient extraction method to extract fat from various tissues. Pérez-Palacios et al. [10] also suggested that although the SO method is
Table 1: Total lipid of beef fat using four extraction methods.

\begin{tabular}{llll}
\hline $\begin{array}{l}\text { Extraction } \\
\text { Method }\end{array}$ & $\begin{array}{l}\text { Initial } \\
\text { Weight }\end{array}$ & $\begin{array}{l}\text { Final } \\
\text { Weight }\end{array}$ & $\begin{array}{l}\text { Total } \\
\text { Lipid (\%) }\end{array}$ \\
\hline SO & 5.0033 & 4.4865 & $89.67^{\mathrm{d}}$ \\
FO & 5.0305 & 4.1114 & $81.73^{\mathrm{b}}$ \\
BD & 5.0451 & 2.7827 & $55.16^{\mathrm{a}}$ \\
HR & 5.0051 & 4.2242 & $84.40^{\mathrm{c}}$ \\
\hline
\end{tabular}

Different superscript means significant difference at $\alpha$ of $5 \%$

also very good for quantifying the total lipid other than the FO method, but the long use of heat in SO can induce lipid oxidation, phospolipid hydrolysis and other lipid chemical modifications. According to Alm [23], fatty acid composition is strongly influenced by several factors such as species, feeding method (intensive or extensive), and the origin of fat (e.g. meat, bone, skin). These can lead to differences in fatty acid composition from different experiments, for example, pentadecanoic acid is measured with a percentage of 1.07-1.08\%. Ahmad Nizar et al. [24] and Guntarti et al. [7] reported that pentadecanoic acid (C15:0) was detected in beef fat, while this fatty acid was not found in Hermanto et al. [3]. In addition, arachic acid (C20:0) of $0.14-0.16 \%$ is detected in this research which is also reported by Hermanto et al. [3] with percentage of $0.33 \%$. In contrast to Guntarti et al. [7] which stated this fatty acid is undetected. While Ahmad Nizar et al. [24] reported that the composition only until linoleic acids (C18:2).

In order to make the differentiation and classification, the fatty acid profiles of beef fat in SO, FO, BD, and HR are subjected to the chemometrics technique of principal component analysis (PCA). PCA is an unsupervised pattern recognition technique widely used in chemometrics study. PCA projects the original data in reduced dimensions defined by the principal components (PCs). This technique is useful when there are correlations present among studied data [25]. Figure 1 demonstrates the score plot of PCA of beef fat in SO, FO, BD, and HR describing the projection of samples defined by the first (PC1) and second (PC2) components.

Figure 1 demonstrates the score plot of PCA of four extraction methods describing the projection of samples defined by the first (PC1) and second (PC2) components. Based on the score plots, it is known that FO can be separated from others in which FO has positive side either in PC1 and PC2. In order to know the number of PCs suggested by the software to be used in PCA model, the residual analysis was constructed. Based on the predicted residual error sum of square values (Figure 2), it can be stated that 3 PCs is necessary for PCA model, 
Table 2: Fatty acid composition of beef fat in four extraction methods using GC-MS.

\begin{tabular}{|c|c|c|c|c|c|}
\hline \multirow[t]{2}{*}{ Fatty acid } & & \multicolumn{4}{|l|}{ Peak area (\%) } \\
\hline & & so & FO & BD & HR \\
\hline Capric & $\mathrm{C} 10: 0$ & $0.10 \pm 0.01^{\mathrm{a}, \mathrm{b}}$ & $0.10 \pm 0.00^{b}$ & $0.09 \pm 0.01^{\mathrm{a}}$ & $0.10 \pm 0.00^{b}$ \\
\hline Lauric & $\mathrm{C} 12: 0$ & $0.26 \pm 0.01^{\mathrm{a}}$ & $0.26 \pm 0.01^{\mathrm{a}}$ & $0.24 \pm 0.01^{\mathrm{a}}$ & $0.26 \pm 0.01^{\mathrm{a}}$ \\
\hline Myristic & C14:0 & $6.71 \pm 0.09^{b}$ & $6.48 \pm 0.04^{a}$ & $6.76 \pm 0.06^{b}$ & $6.70 \pm 0.08^{b}$ \\
\hline Myristoleic & C14:1 & $0.81 \pm 0.03^{a}$ & $0.79 \pm 0.00^{a}$ & $0.73 \pm 0.01^{a}$ & $0.81 \pm 0.06^{a}$ \\
\hline Pentadecanoic & C15:0 & $1.08 \pm 0.04^{\mathrm{a}}$ & $1.08 \pm 0.03^{\mathrm{a}}$ & $1.07 \pm 0.01^{\mathrm{a}}$ & $1.08 \pm 0.01^{\mathrm{a}}$ \\
\hline Palmitic & $\mathrm{C} 16: 0$ & $27.17 \pm 0.08^{a}$ & $26.34 \pm 0.37^{a}$ & $27.65 \pm 0.25^{\mathrm{a}}$ & $27.38 \pm 0.93^{a}$ \\
\hline Palmitoleic & C16:1 & $2.09 \pm 0.03^{a}$ & $2.37 \pm 0.06^{b}$ & $2.12 \pm 0.04^{a}$ & $2.42 \pm 0.11^{\mathrm{b}}$ \\
\hline Margaric & C17:0 & $3.01 \pm 0.06^{\mathrm{a}}$ & $3.06 \pm 0.05^{\mathrm{a}}$ & $2.98 \pm 0.01^{\mathrm{a}}$ & $2.99 \pm 0.01^{a}$ \\
\hline Cis-10-heptadecanoic & $\mathrm{C} 17: 1$ & $0.64 \pm 0.00^{a}$ & $0.65 \pm 0.01^{\mathrm{a}}$ & $0.61 \pm 0.04^{\mathrm{a}}$ & $0.66 \pm 0.01^{\mathrm{a}}$ \\
\hline Stearic & C18:0 & $23.01 \pm 0.00^{a}$ & $23.33 \pm 0.52^{\mathrm{a}}$ & $23.19 \pm 0.33^{\mathrm{a}}$ & $23.05 \pm 0.53^{a}$ \\
\hline Oleic & C18:1 & $31.56 \pm 0.31^{a}$ & $31.70 \pm 0.45^{\mathrm{a}}$ & $30.75 \pm 0.66^{a}$ & $31.74 \pm 0.31^{\mathrm{a}}$ \\
\hline Linoleic & C18:2 & $2.56 \pm 0.03^{b}$ & $2.71 \pm 0.02^{c}$ & $2.48 \pm 0.04^{\mathrm{a}}$ & $2.55 \pm 0.02^{\mathrm{a}, \mathrm{b}}$ \\
\hline Linolenic & C18:3 & $0.32 \pm 0.01^{b}$ & $0.33 \pm 0.01^{b}$ & $0.27 \pm 0.02^{\mathrm{a}}$ & $0.30 \pm 0.00^{b}$ \\
\hline Nonadecanoic & C19:0 & $0.15 \pm 0.00^{a}$ & $0.16 \pm 0.01^{a}$ & nd & nd \\
\hline Cis-10- Nonadecanoic & C19:1 & nd & $0.11 \pm 0.01$ & nd & nd \\
\hline Arachic & C20:0 & $0.15 \pm 0.01^{a}$ & $0.16 \pm 0.01^{a}$ & nd & nd \\
\hline Cis-11-eicosenic & $C 20: 1$ & $0.18 \pm 0.00^{\mathrm{a}}$ & $0.19 \pm 0.01^{a}$ & nd & nd \\
\hline Saturated Fatty Acid & & $61.62 \pm 0.14^{\mathrm{a}, \mathrm{b}}$ & $60.94 \pm 0.21^{\mathrm{a}}$ & $61.96 \pm 0.02^{b}$ & $61.55 \pm 0.49^{a, b}$ \\
\hline Unsaturated Fatty Acid & & $38.16 \pm 0.23^{a, b}$ & $38.82 \pm 0.35^{b}$ & $36.94 \pm 0.78^{a}$ & $38.47 \pm 0.51^{\mathrm{b}}$ \\
\hline
\end{tabular}

The value of each fatty acid is a mean \pm standard deviation of two replications. Each row with different letters is significantly different $(\mathrm{P}$ $<0.05)$. nd is not detected

because at this PC number, PRESS value reach minimal [26]. The extraction of fat from food is crucial in the food industry for product formulation and because food labels must report both saturated and unsaturated fat content. From these data (it can be seen that), the Folch method and GCMS measurements can analyze fatty acids both saturated and unsaturated better than other solventbased extraction methods. In addition, the Folch method can extract rapidly low, moderate, high and very high fat contents in food [10].

\subsection{Finger print analysis of beef fat}

The use of FTIR spectroscopy as a fat and oil analysis technique is being developed. The simple method, which does not require much preparation, short time and relatively cheap are the advantages of this technique [27]. The extracted beef fat samples are scanned with Thermofisher Scientific Nocolet iS5 FTIR, in IR area with wavenumbers of $4000-600 \mathrm{~cm}^{-1}$ and the resulted FTIR spectra which can be seen in Figure 3. Based on these,

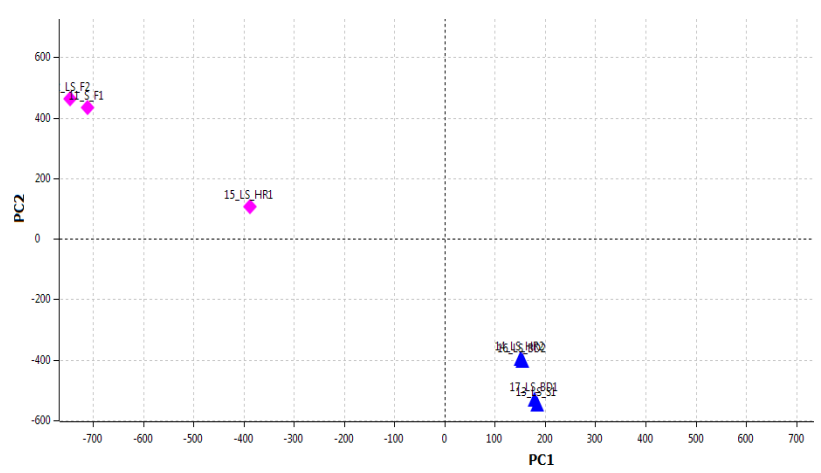

Figure 1: The score plot of PCA model using fatty acid composition of beef fat in SO, FO, BD, and HR.

several functional groups can be seen which are contained in beef fat (Table 3 ).

Triglycerides which are fat-forming components are reflected in the obtained FTIR spectra. High intensity is seen in the region of the wave numbers 2851-2921 $\mathrm{cm}^{-1}$, this area indicates the presence of $-\mathrm{C}-\mathrm{H}(\mathrm{CH} 2)$ with vibration mode of asymmetric or symmetric stretching. This is consistent with the fatty acid composition which is 


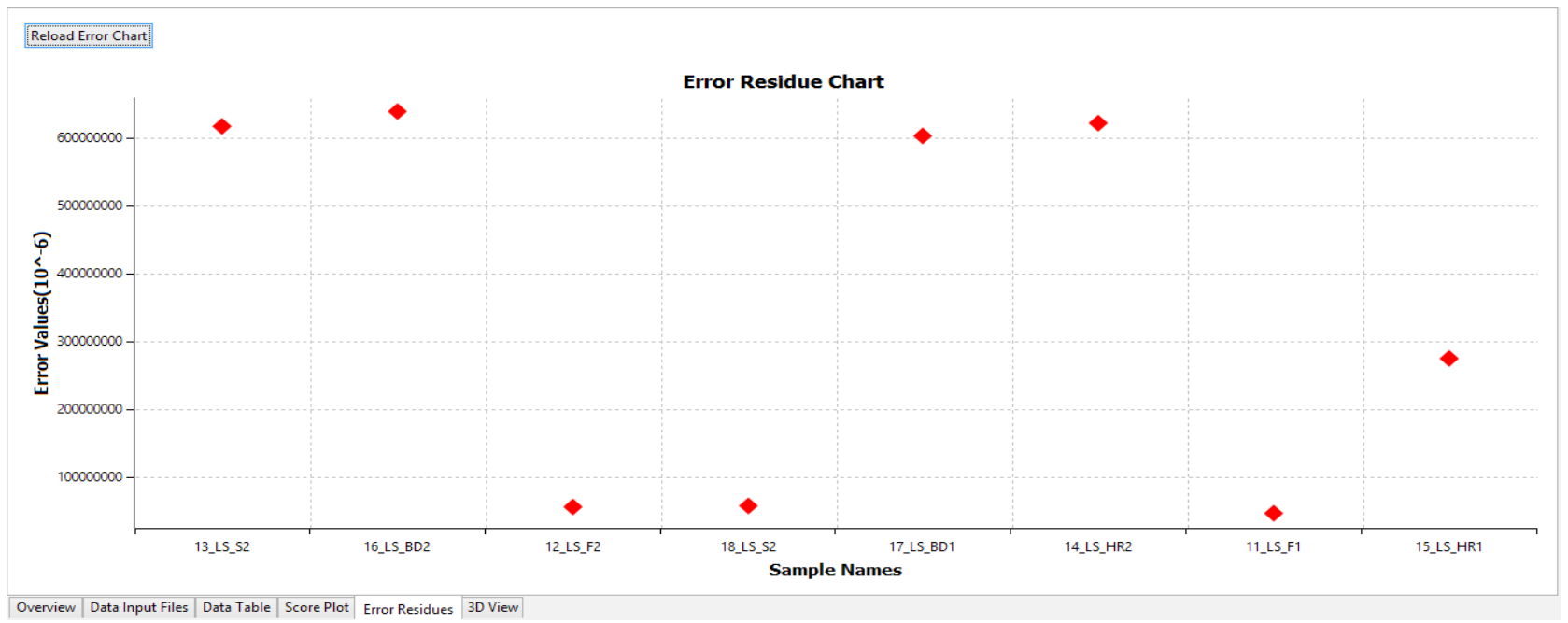

Figure 2: The residual error of PCA model for determination of optimum principle components used in PCA model.

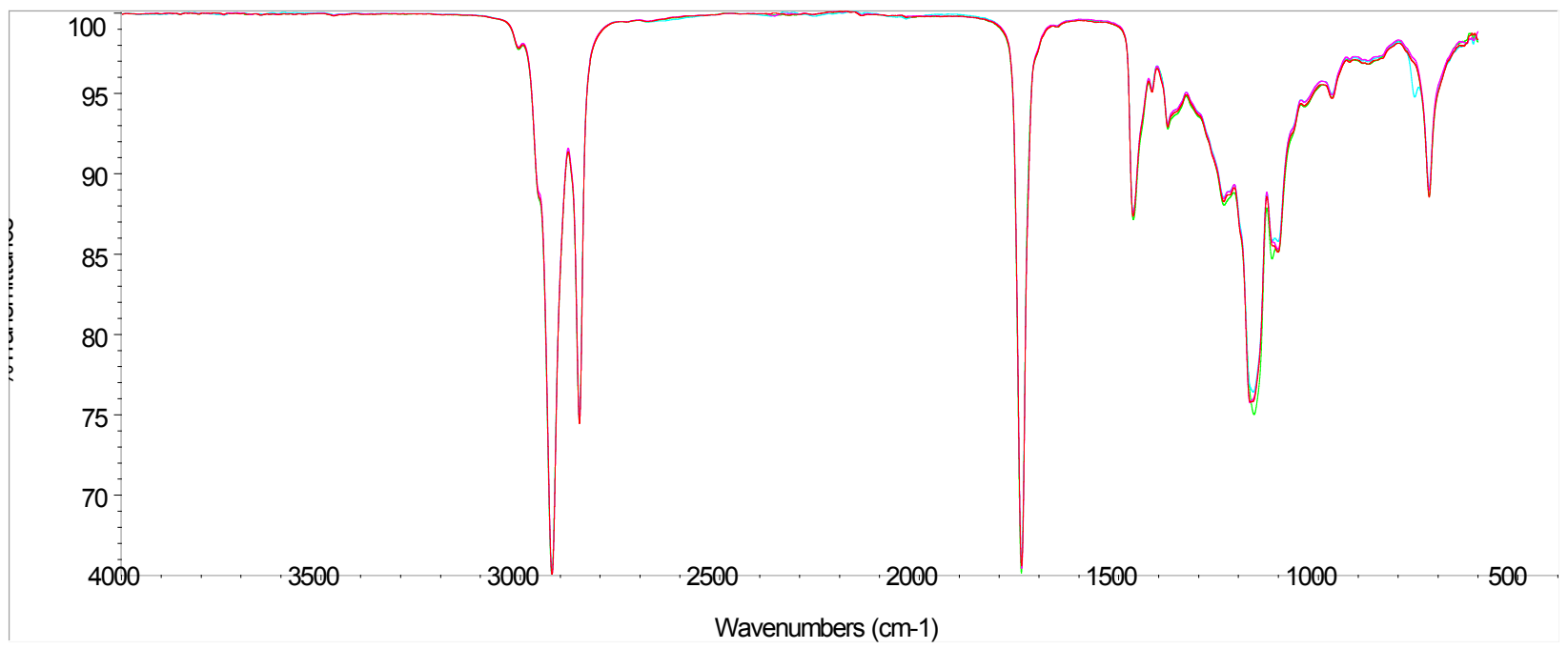

Figure 3: FTIR spectra of beef fat with four extraction method.

dominated by long chain single fatty acids. High intensity at the wavenumber of $1741-1743 \mathrm{~cm}^{-1}$ indicates a high content of stretching $-\mathrm{C}=\mathrm{O}$. This group is a functional group for the ester compound which in this case is a fatty acid [28], whereas in the wavenumbers of 1099-1171 $\mathrm{cm}^{-1}$ indicates the presence of stretching C-O from C-O-C. This cluster connects fatty acid esters with glycerol. The content of many unsaturated fatty acids is also reflected in the wavenumbers of $721 \mathrm{~cm}^{-1}$ which shows the presence of bending $=\mathrm{C}-\mathrm{H}$ group. In addition, from these data show that the obtained spectra are no significantly different from all extraction method.

Vibration mode of stretching C-O-C is found in beef fat samples using FTIR. It can be determined the magnitude of the force constant by assuming inharmonic oscillation is shown in Table 4. The force constant is
Table 3: Functional group and vibration mode on beef fat based on FTIR spectra.

\begin{tabular}{|c|c|c|c|c|}
\hline \multicolumn{4}{|c|}{ Wavenumber $\left(\mathrm{cm}^{-1}\right)$} & \multirow{2}{*}{$\begin{array}{l}\text { Functional group } \\
\text { and vibrational } \\
\text { mode }\end{array}$} \\
\hline so & FO & BD & HR & \\
\hline 721.3 & 721.33 & 721.32 & 721.25 & $=\mathrm{C}-\mathrm{H}$, bending \\
\hline 1114.92 & 1099.88 & 1100.01 & 1099.94 & C-O-C, stretching \\
\hline 1159.97 & 1162.01 & 1170.24 & 1169.08 & C-O-C, stretching \\
\hline 1376.3 & 1376.49 & 1376.59 & 1376.55 & $=\mathrm{C}-\mathrm{H}-$ (cis), bending \\
\hline 1462.7 & 1463.14 & 1463.26 & 1463.22 & $\begin{array}{l}-\mathrm{C}-\mathrm{H}-(\mathrm{CH} 2-\mathrm{CH} 3) \\
\text { bending }\end{array}$ \\
\hline 1743.39 & 1743.01 & 1742.59 & 1742.78 & $C=0$, stretching \\
\hline 2851.89 & 2851.66 & 2851.42 & 2851.5 & $\begin{array}{l}-\mathrm{C}-\mathrm{H}(\mathrm{CH} 2) \text {, } \\
\text { stretching }\end{array}$ \\
\hline 2920.8 & 2920.4 & 2919.97 & 2920.14 & $\begin{array}{l}-\mathrm{C}-\mathrm{H}(\mathrm{CH} 2) \text {, } \\
\text { stretching }\end{array}$ \\
\hline
\end{tabular}


Table 4: Anharmonic constant value $\left(\mathrm{Nm}^{-1}\right)$ with asymmetry stretching vibration of $\mathrm{C}-\mathrm{O}$ from $\mathrm{C}-\mathrm{O}-\mathrm{C}$.

\begin{tabular}{lllllll}
\hline $\begin{array}{l}\text { Extraction } \\
\text { method }\end{array}$ & $\begin{array}{l}\Delta \varepsilon_{1} \\
\left(\mathrm{~cm}^{-1}\right)\end{array}$ & $\begin{array}{l}\Delta \varepsilon_{2} \\
\left(\mathrm{~cm}^{-1}\right)\end{array}$ & $\mathbf{x}_{\mathrm{e}}$ & $\overline{\boldsymbol{\omega}}_{\mathrm{e}}$ & $\begin{array}{l}\mathrm{f} \\
\left(10^{13} \mathrm{~Hz}\right)\end{array}$ & $\begin{array}{l}\mathbf{k} \\
\left(\mathrm{Nm}^{-1}\right)\end{array}$ \\
\hline SO & 1114.92 & 1159.97 & 0.2448 & 2184.79 & 6.5544 & 1929.351 \\
FO & 1099.88 & 1162.01 & 0.2427 & 2137.63 & 6.4129 & 1846.958 \\
BD & 1100.01 & 1170.24 & 0.2418 & 2129.79 & 6.3893 & 1833.435 \\
HR & 1099.94 & 1169.08 & 0.2419 & 2130.74 & 6.3922 & 1835.071 \\
\hline
\end{tabular}

Example calculation of force constant, $\mathrm{k}$, (SO extraction):

- Using equations (1) and (2) and comparing them, where $\Delta \varepsilon_{1}$ and $\Delta \varepsilon_{2}$ are $1114.92 \mathrm{~cm}^{-1}$ and $1159.97 \mathrm{~cm}^{-1}$, respectively: are obtained

$>\frac{1114.92}{1159.97}=\frac{\bar{\omega}_{e}\left(1-2 x_{e}\right)}{2 \bar{\omega}_{e}\left(1-3 x_{\mathrm{e}}\right)}$

$>(1114.92) \times 2 \times\left(1-3 \mathrm{x}_{\mathrm{e}}\right)=(1159.97) \times\left(1-2 \mathrm{x}_{\mathrm{e}}\right)$

$>\mathrm{x}_{\mathrm{e}}=0.2448$

- So:

$>\bar{\omega}_{\mathrm{e}}\left(1-2 \mathrm{x}_{\mathrm{e}}\right)=1114.92$

$>\bar{\omega}_{\mathrm{e}}(1-2(0.2448))=1114.92$

$>\quad \bar{\omega}_{\mathrm{e}}=\frac{1114.92}{(1-2(0.2448))}=2184.79 \mathrm{~cm}^{-1}$

- By using equation (3):

$>f=\frac{c}{\lambda}=c \bar{\omega}_{e}=3 \times 10^{10} \mathrm{~cm} \mathrm{~s}^{-1} \times 2184.79 \mathrm{~cm}^{-1}=6.5544 \times 10^{13} \mathrm{~Hz}$

- and:

$>\mu=\frac{M m}{M+m}=\frac{1.944 \times 10^{-26} \mathrm{~kg} \times 2.655 \times 10^{-26} \mathrm{~kg}}{\left(1.944 \times 10^{-26} \mathrm{~kg}+2.655 \times 10^{-26} \mathrm{~kg}\right)}=1.5444 \times 10^{-26} \mathrm{~kg}$

- So by substituting them into equation (4), then

$>k=4 \pi^{2} f^{2} \mu=4 \times(3.14)^{2} \times\left(6.5544 \times 10^{13}\right)^{2} \times 1.5444 \times 10^{-26} \mathrm{~N} / \mathrm{m}$

$>k=1929.531{\mathrm{~N} . \mathrm{m}^{-1}}^{-1}$

identified as the bonding strength of the molecule. The inharmonic constant $\left(X_{e}\right)$ of C-O from C-O-C can be calculated using the comparison of equations (1) and (2)

$$
\begin{aligned}
\Delta \varepsilon & =\bar{\omega}_{e}\left(1-2 x_{e}\right) \mathrm{cm}^{-1} \\
\Delta \varepsilon & =2 \bar{\omega}_{e}\left(1-3 x_{e}\right) \mathrm{cm}^{-1}
\end{aligned}
$$

where $\Delta \varepsilon$ and $\bar{\omega}_{e}$ are wavenumbers $\left(\mathrm{cm}^{-1}\right)$. So, the value of inharmonic constant $\left(X_{e}\right)$ of C-O are $0.2418-0.2448$ and $\bar{\omega}_{e}$ values are $2129.79-2184.79 \mathrm{~cm}^{-1}$. Brooks [29] stated that $\bar{\omega}_{e}$ value of $\mathrm{C}-\mathrm{O}$ is $2170 \mathrm{~cm}^{-1}$. The given infrared rays will be absorbed by the molecular vibrations if the frequency of infrared is equal to the frequency of the molecular vibration or is called resonance. The frequency that occurs can be calculated using equation (3)

$$
f=\frac{c}{\lambda}=c \bar{\omega}_{e}
$$

where $\mathrm{c}$ is the speed of light $\left(3 \times 1010 \mathrm{~cm} \cdot \mathrm{s}^{-1}\right)$, so that the frequency values are $6.3893-6.5544 \times 1013 \mathrm{~Hz}$ is obtained. Then, this value is substituted into equation (4) to obtain the force constant of C-O which are in the range of 1833.435 - 1929.351 N.m ${ }^{-1}$. These are consistent with Brooks [29]



$$
f=\frac{1}{2 \pi} \sqrt{\frac{k}{\mu}} \text { or } k=4 \pi^{2} f^{2} \mu
$$

where $\mu=\frac{M m}{M+2 m}$, with $\mathrm{M}$ and $\mathrm{m}$ are $\mathrm{C}$ mass $\left(1.944 \times 10^{-26}\right.$ $\mathrm{kg})$ and $\mathrm{O}$ mass $\left(2.655 \times 10^{-26} \mathrm{~kg}\right)$, respectively.

\section{Conclusion}

The percentages of total lipid in raw beef by Soxhlet, Folch, Bligh \& Dyer, and Hara \& Radin methods were 89.67\%, $81.73 \%, 55.16 \%$, and $84.40 \%$, respectively. Statistical analysis showed that saturated fatty acids in almost all methods were not significantly different than a 5\% level, while polyunsaturated fatty acid in Folch showed a higher amount than the others. In addition, PCA analysis showed that only the Folch method can be differentiated and has minimal residual error values. The results of finger print analysis showed that the extraction methods which were used were not significantly different. The peaks were formed at wavenumbers of about $721 \mathrm{~cm}^{-1}, 1100 \mathrm{~cm}^{-1}, 1160$ $\mathrm{cm}^{-1}, 1376 \mathrm{~cm}^{-1}, 1463 \mathrm{~cm}^{-1}, 1743 \mathrm{~cm}^{-1}, 2851 \mathrm{~cm}^{-1}$, and 2920 $\mathrm{cm}^{-1}$ which showed stretching vibration modes of $\mathrm{C}-\mathrm{O}$ ester groups from C-O-C at 1100 and $1160 \mathrm{~cm}^{-1}$ where force constant of C-O was about $1860 \mathrm{~N} . \mathrm{m}^{-1}$. These data showed that Folch was the best method for extracting beef fat. 
Acknowledgement: We gratefully acknowledge the funding from Grant of Penelitian Kerjasama Antar Perguruan Tinggi (PKPT) from the Ministry of Research, Technology and Higher Education, Republic of Indonesia under contract No 0826/K4/KM/2018 and we also acknowledge PT Alphasains Dinamika for the use of Thermo Scientific Nicolet iS5 FT-IR spectrometer.

Conflict of interest: Authors state no conflict of interest.

\section{References}

[1] Czarniecki J., GC/MS analysis for unsaturated fat content in animal feed, Nafag Company, Gossau, Switzerland, 2003.

[2] Nina Naqiyah A.N., Marikkar J.M.N., Dzulkifly M.H., Differentiation of lard, chicken fat, beef fat, and mutton fat by GCMS and EA-IRMS techniques, J. Oleo. Sci., 2013, 63, 459 464.

[3] Hermanto S., Muawanah A., Harahap R., Profil dan karakteristik lemak hewani (ayam, sapi dan babi) hasil analisa FTIR dan GCMS, Jurnal Kimia Valensi, 2008, 1, 102. (n Indonesian)

[4] Rodriguez-Saona L.E., Allendorf M.E., Use of FTIR for rapid authentication and detection of adulteration of food, Annu Rev Food Sci Technol., 2011, 2, 467-83.

[5] Nurrulhidayah A.F., Che Man Y.B., Rohman A., Amin I., Shuhaimi M., Khatib A., Authentication analysis of butter from beef fat using Fourier Transform Infrared (FTIR) spectroscopy coupled with chemometrics, International Food Research Journal, 2013, 20, 1383-1388.

[6] Rohman A., Sismindari, Erwanto Y., Che Man Y.B., Analysis of pork adulteration in beef meatball using Fourier transform infrared (FTIR) spectroscopy, J. Meat Sci., 2011, 88, 91-95.

[7] Guntarti A., Martono S., Yuswanto, Rohman A., FTIR spectroscopy in combination with chemometrics for analysis of wild boar meat in meatball formulation, Asian Journal of Biochemistry, 2015, 10, 165-172.

[8] Manirakiza P., Covaci A., Schepens P., Comparative study on total lipid determination using Soxhlet, Roese-Gottlieb, Bligh \& Dyer, and modified Bligh \& Dyer extraction methods, Journal of food Composition and Analysis, 2001, 14, 93-100.

[9] Ewald G., Bremle G., Karlsson A., Differences between Bligh and Dyer and Soxhlet extraction of PCBs and lipids from fat and lean fish muscle: Implications for data evaluation, Marine Pollution Bulletin, 1998, 36, 222-230.

[10] Pérez-Palacios T., Ruiz J., Martín D., Muriel E., Antequera T., Comparison of different methods for total lipid quantification in meat and meat products, J. Food Chem., 2008, 110, 1025-1029.

[11] Jensen W.B., The origin of the soxhlet extractor, J. of Chemical Education., 2007, 84, 1913-1914.

[12] Aminullah, Mardiah, Hakim L., Argani A.P., Syahbirin G., Effect of fat extraction methods on fatty acid and infrared profiles of chicken fat using GC-MS and FTIR, Asian Journal of Chemistry, 2018, 30, 1317-1320.

[13] Iverson S.J., Cooper M.H., Lang S.C.L., Comparison of the Bligh and Dyer and Folch methods for total lipid determination in a broad range of marine tissue, Lipids, 2001, 36.
[14] [AOAC] Association of Official Analytical Chemist., Official method of analysis of association of official analytical chemist, $14^{\text {th }}$ ed, AOAC inc, 1995.

[15] Folch J., Lees M., Sloane Stanley G.H., A simple method for the isolation and purification of total lipids from animal tissues, J. Biol. Chem., 1957, 226, 497-509.

[16] Bligh E.G., Dyer W.J., A rapid method of total lipid extraction and purification, Can. J. Biochem. Physiol., 1959, 37, 911-917.

[17] Hara A., Radin N.S., Lipid extraction of tissues with a lowtoxicity solvent, J.Anal. Biochem., 1978, 90, 420-426.

[18] Metcalfe L., Schmitz A., The rapid preparation of fatty acid esters for gas chromatographic analysis, Anal. Chem., 1961, 33, 363-4.

[19] Schlechtriem C., Fliedner A., Schäfers C., Lipid measurement, 2009 Available on http://www.oecd.org/chemicalsafety/ testing/48470247.pdf

[20] Aminullah, Mardiah, Riandi M.R, Argani A.P, Syahbirin G., Kemala T., Kandungan total lipid lemak ayam dan babi berdasarkan perbedaan jenis metode ekstraksi lemak. Jurnal Agroindustri Halal, 2018, 4, 94-100. In Indonesia.

[21] Sharma H., Giriprasad R., Goswami M., Animal fat-processing and its quality control, J. Food Process Technol., 2013, 4, 8.

[22] Rohman A., Triyana K., Sismindari, Erwanto Y., Differentiation of lard and other animal fats based on triacylglycerols composition and principal component analysis, International Food Research Journal, 2012, 19, 475-479.

[23] Alm M., Animal Fats, 2013, Available from http://lipidlibrary. aocs.org/OilsFats/content.cfm? ItemNumber $=40320$ (last consul 2017/07/02).

[24] Ahmad Nizar N.N., Nazrim Marikkar J.M., Hashim D.M., Differentiation of lard, chicken fat, beef fat and mutton fat by GCMS and EA-IRMS techniques, J. Oleo. Sci., 2013, 62, 459464.

[25] Cserhati T., Data evaluation in chromatography by principal component analysis, Biomed Chromatography, 2010, 24, 20-28.

[26] Sedman J., Van de Voort F. R., Ismail A.A., Application of fourier transform infrared spectroscopy in new techniques and application in lipid analysis, AOCS Press, Champaign, Illinois, USA, 1997.

[27] Fajriati I., Aisyah L., Teknologi pangan hewani dalam wacana halal dan haram, Al-Qānūn, 2010, 13. In Indonesia.

[28] Hart D.J., Hadad C.M., Craine L.E., and Hart H., Organic chemistry: a short course, Brooks/Cole, Belmont USA, 2007.

[29] Brooks R.L., The fundamentals of atomic and molecular physics, Springer, New York, 2013.

Supplemental Material: The online version of this article offers supplementary material (https://doi.org/10.1515/chem-2018-0109). 